J. Dairy Sci. 99:1549-1559

http://dx.doi.org/10.3168/jds.2015-10131

(C) American Dairy Science Association ${ }^{\circledR}, 2016$.

\title{
Longitudinal changes in adipose tissue of dairy cows from late pregnancy to lactation. Part 1: The adipokines apelin and resistin and their relationship to receptors linked with lipolysis
}

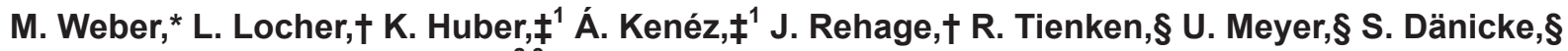 \\ H. Sauerwein, ${ }^{*}$ and M. Mielenz ${ }^{* 2,3}$ \\ *Institute of Animal Science, Physiology and Hygiene Unit, University of Bonn, 53115 Bonn, Germany \\ †Clinic for Cattle, University of Veterinary Medicine Hannover, 30173 Hannover, Germany \\ $\ddagger$ Department of Physiology, University of Veterinary Medicine Hannover, 30173 Hannover, Germany \\ §Institute of Animal Nutrition, Friedrich-Loeffler-Institute (FLI), Federal Research Institute for Animal Health, 38116 Braunschweig, Germany
}

\section{ABSTRACT}

The transition from pregnancy to lactation is characterized by major changes in glucose and adipose tissue metabolism. Anti- and prolipolytic pathways mediated via the hydroxycarboxylic acid receptors 1 (HCAR 1 ) and 2 (HCAR2) and tumor necrosis factor- $\alpha$ receptor 1 (TNFR1), as well as the adipokines apelin and resistin, are likely involved in regulating these processes. This study aimed to determine the mRNA abundance of the aforementioned receptors in both subcutaneous and visceral adipose tissue, to characterize the adipokine concentrations in serum, and to test the effects of feeding diets with either high or low portions of concentrate and a concomitant niacin supplementation from late gestation to early lactation. Twenty pluriparous German Holstein cows were all kept on the same silage-based diet until d 42 antepartum, when they were allocated to 2 feeding groups: until d 1 antepartum, 10 animals each were assigned to either a high-concentrate (60:40 concentrate-to-roughage ratio) or a low-concentrate diet (30:70). Both groups were further subdivided into a control and a niacin group, the latter receiving 24 $\mathrm{g} / \mathrm{d}$ of nicotinic acid from d -42 until 24 . From d 1 to 24 postpartum, the concentrate portion was increased from 30 to $50 \%$ for all cows. Biopsies of subcutaneous (SCAT) and retroperitoneal adipose tissue (RPAT) were taken at $\mathrm{d}-42,1,21$, and 100 relative to parturition. Blood samples were drawn along with the biopsies and

\footnotetext{
Received July 18, 2015.

Accepted October 16, 2015.

${ }^{1}$ Present address: Institute of Animal Science, University of Hohenheim, 70599 Stuttgart-Hohenheim, Germany

${ }^{2}$ Present address: Institute of Nutrition Physiology "Oskar Kellner," Leibniz Institute for Farm Animal Biology (FBN), 18196 Dummerstorf, Germany

${ }^{3}$ Corresponding author: mielenz@fbn-dummerstorf.de
}

on $\mathrm{d}-14,3,7,14$, and 42 . The concentrations of the adipokines apelin and resistin in serum were measured via ELISA. The mRNA of the 3 receptors in AT was quantified as well as the protein abundance of HCAR2 by Western blot. The feeding regimen did not affect the variables examined. The concentrations of apelin remained fairly constant during the observation period, whereas the resistin concentrations increased toward parturition and decreased to precalving levels within 1 wk after calving. The mRNA abundance of HCAR1, HCAR2, and TNFR1 changed in SCAT and RPAT during the considered time period. For the HCAR2 protein, time-dependent changes were restricted to SCAT. The mRNA abundance of all receptors was greater in RPAT than in SCAT. The tissue-specific correlations observed between the receptors point to a link between these factors and may indicate different regulatory roles in the respective tissues. This study provides insight into the complex metabolic adaptations during the transition period and supports a differential regulation of lipolysis among SCAT and RPAT in dairy cows.

Key words: dairy cow, transition period, hydroxycarboxylic acid receptor, apelin, resistin

\section{INTRODUCTION}

In dairy cows, the transition from late gestation to lactation is characterized by major metabolic changes. The requirements for nutrients increases rapidly after calving and not all animals can increase nutrient intake fast enough to meet those requirements (Grummer, 1995). Homeorhetic adaptations are necessary to facilitate the nutrient partitioning toward the mammary gland and to cover the energy demands for milk production (Bauman and Currie, 1980). These adaptations are accompanied by decreased peripheral insulin sensitivity (Bell and Bauman, 1997) and increased lipolysis (McNamara and Hillers, 1986). 
As discussed by Duncan et al. (2007), the hydrolysis of triacylglycerols displays the initial step of lipolysis. In adipose tissue of dairy cows this process is mediated via phosphorylation of hormone-sensitive lipase (HSL) under stimulation of catecholamines (McNamara and Hillers, 1986; Sumner and McNamara, 2007; Locher et al., 2011). The increased lipolysis is at least partly mediated via an increased expression of the $\beta$-adrenergic receptors, with the $\beta-2$ receptors being suggested as the most important subtype (Sumner and McNamara, 2007; Sumner-Thomson et al., 2011). The adipocytederived factors (adipokines) apelin and resistin, as well as the hydroxycarboxylic acid receptors 1 (HCAR1) and 2 (HCAR2) and tumor necrosis factor- $\alpha$ receptor 1 (TNFR1) are likely relevant as regulatory elements in these processes.

Apelin is an adipokine, which is upregulated by insulin (Boucher et al., 2005) and was shown to increase glucose uptake by adipose tissue (AT) and skeletal muscle in mice (Dray et al., 2008). It is supposed to play a physiological role in glucose metabolism (Dray et al., 2008). In addition, apelin decreases lipolysis in mice by inhibiting the phosphorylation of HSL (Yue et al., 2011). In dairy cows, apelin was demonstrated in serum and milk (Aydin, 2013), but the time-course of the serum apelin concentrations during lactation was unknown.

The prolipolytic tumor necrosis factor- $\alpha$ (TNF- $\alpha$ ), whose main effects are mediated by its receptor TNFR1 (Sethi et al., 2000), was shown to upregulate apelin expression (Daviaud et al., 2006); thus, a negative feedback loop has been suggested between these 2 factors (Yue et al., 2011). The abundance of TNF- $\alpha$ mRNA in bovine subcutaneous AT (SCAT) was reported to increase from wk 8 antepartum (a.p.) to the day of parturition without further change until 5 wk thereafter (Sadri et al., 2010), to remain unchanged when considering pluriparous cows from d 21 a.p. to 252 DIM, or to increase in primiparous cows from $\mathrm{d} 1$ to d 42 postpartum (p.p.) (Saremi et al., 2014). To our knowledge, the mRNA expression pattern of TNFR1 in bovine AT is still unknown.

The adipokine resistin is associated with blood glucose concentrations and insulin sensitivity (Steppan et al., 2001). Recently, the plasma resistin concentrations in dairy cows were demonstrated to increase $1 \mathrm{wk}$ after calving; moreover, recombinant resistin stimulated lipolysis in vitro (Reverchon et al., 2014).

The receptors HCAR1 and HCAR2 belong to the family of G-protein-coupled receptors and are activated by hydroxylated carboxylic acids (Offermanns et al., 2011). The receptor HCAR1, which is mainly expressed on adipocytes (Wise et al., 2003), mediates insulin-induced antilipolytic effects via binding lactate (Cai et al., 2008), a quantitatively important substrate for gluconeogenesis next to propionate (Aschenbach et al., 2010). After parturition, the hepatic uptake of lactate increases without affecting the circulating concentrations (Larsen and Kristensen, 2009). Significant amounts of lactate are produced by the ruminal microbes when cows are fed a diet rich in starch (Aschenbach et al., 2010).

The receptor HCAR2 is activated by its endogenous ligand BHB (Gille et al., 2008), as well as by pharmacological doses of nicotinic acid, and exerts antilipolytic effects after binding of its ligands (Tunaru et al., 2003). In humans and mice, HCAR2 is mainly expressed on adipocytes and immune cells (Tunaru et al., 2003; Wise et al., 2003). In cattle, HCAR2 was also found in different brain regions, including the hypothalamus; this might enable the central nervous system to sense the circulating BHB concentrations (Titgemeyer et al., 2011). Recently, the mRNA abundance of HCAR2 was shown to decrease from d 21 a.p. to d 105 p.p. in bovine SCAT (Friedrichs et al., 2014). Both, HCAR1 and HCAR2 are regulated via peroxisome proliferatoractivated receptor $\gamma$ (Jeninga et al., 2009). During the transition period, AT is important for providing energy in the form of fatty acids (Drackley, 1999).

Studies in humans and rodents have shown that AT from different sites (i.e., visceral AT and SCAT) differ in their metabolic activity (Smith and Zachwieja, 1999). Comparable to SCAT, retroperitoneal AT (RPAT) is not draining into the portal circulation (Rebuffé-Scrive et al., 1989; Björntorp, 1990). Further, RPAT contains more transcripts of genes related to lipogenesis and lipolysis, whereas the mRNA of genes related to fatty acid $\beta$-oxidation are more abundant in the portal draining mesenteric AT (Rebuffé-Scrive et al., 1989; Palou et al., 2009). To our knowledge, less data are available on RPAT dynamic during the transition period of dairy cows. In primiparous German Holstein cows with rather low BW and milk production, the mass of SCAT was shown to change only marginally during the first $105 \mathrm{~d}$ of lactation, whereas the RPAT depot decreased significantly during this time (von Soosten et al., 2011). Furthermore, the postpartum feeding regimen influences the phosphorylation pattern of HSL, especially in RPAT (Locher et al., 2011); this suggests that RPAT might be more sensitive to periparturient challenges than SCAT (Locher et al., 2011). Therefore, the aim of the current study was to test whether feeding different amounts of concentrate in the prepartum period and a concomitant niacin supplementation, both aiming at inducing differences in energy balance, may affect the serum concentrations of apelin and resistin as 
well as the mRNA abundance of HCAR1, HCAR2, and TNFR1. Furthermore, we hypothesized that TNFR1 and HCAR1 are involved in the regulation of lipolysis in an AT depot-specific manner. Using serum samples and biopsies from SCAT and RPAT, we aimed to determine changes in serum concentrations and mRNA expression related to treatment and time from late pregnancy to lactation.

\section{MATERIALS AND METHODS}

\section{Animals and Feeding}

The experiment was carried out between d 42 a.p. and d 100 p.p. at the experimental station of the Institute of Animal Nutrition, Friedrich-Loeffler-Institute, Braunschweig, Germany, and approved by The Lower Saxony State Office for Consumer Protection and Food Safety, Oldenburg, Germany.

Twenty pluriparous German Holstein cows were kept in a freestall housing system with free access to water. Prior to the experiment, all cows received the same silage-based diet as a TMR. At d -42 , the first biopsies were collected and afterward the animals were randomly assigned to 2 feeding groups $(\mathrm{n}=10)$ differing in the concentrate-to-roughage ratio. Cows of the lowconcentrate (LC) group received a diet with a 30:70 concentrate-to-roughage ratio (on a DM basis), whereas the ratio for cows of the high-concentrate $(\mathbf{H C})$ group was 60:40. Both groups were further subdivided into a control and a niacin group, the latter receiving 24 $\mathrm{g} / \mathrm{d}$ of nicotinic acid (Mianyang Vanetta Pharmaceutical Technology Co. Ltd., Sichuan, China) from d -42 until d 24. After parturition, a diet with a concentrate portion of $30 \%$ was fed to all cows and was increased to $50 \%$ within $16 \mathrm{~d}$ for the LC group and within 24 $\mathrm{d}$ for the $\mathrm{HC}$ group. The roughage mixture contained each $50 \%$ grass silage and $50 \%$ corn silage on DM basis. The nutrient contents of concentrate and roughage are presented in Table 1.

\section{Blood Sampling and Analyses}

Blood samples were drawn from the jugular vein on $\mathrm{d}-42,-14,1,3,7,14,21,42$, and 100 relative to calving. After clotting, blood was centrifuged at 2,000 $\times g$ for $15 \mathrm{~min}$ at $15^{\circ} \mathrm{C}$ and serum was stored at $-80^{\circ} \mathrm{C}$. The total serum apelin concentrations were measured using a commercially available ELISA kit (Phoenix Pharmaceuticals, Burlingame, CA) specific for bovine apelin (intra- and interassay coefficients of variation were 5.4 and $9.3 \%$, respectively). The resistin concentrations in serum were determined with a commercially available ELISA kit (Uscn Life Science Inc., Wuhan, China); the intra- and interassay coefficients of variation were 9.1 and $12.5 \%$, respectively. Serum lactate concentrations were also measured using a commercially available kit system (MAK-064, Sigma Aldrich, Nümbrecht, Germany).

\section{Sampling of Adipose Tissue}

Adipose tissue (SCAT and RPAT) was biopsied 4 times on d 42 a.p., d 1 after calving, and on d 21 and 100 p.p. Samples were taken under aseptic conditions from the SCAT depot at the tail head and the RPAT depot below the lumbar vertebrae, as described in detail by Locher et al. (2011). After rinsing in sterile saline solution to reduce surgically induced blood contamination, the tissue samples were immediately frozen in liquid nitrogen and stored at $-80^{\circ} \mathrm{C}$ until RNA extraction.

\section{Western Blot Analysis}

Details of the protein extraction and the Western Blot analysis are described by Kenéz et al. (2014). In brief, the tissue samples were homogenized in a lysis buffer containing a protease inhibitor cocktail (CompleteMini, Roche Diagnostics GmbH, Mannheim, Germany) and a phosphatase inhibitor cocktail (PhosStop, Roche Diagnostics $\mathrm{GmbH}$ ). After centrifugation at 1,000 $\times g$ for

Table 1. Nutrient contents of concentrates and roughage

\begin{tabular}{|c|c|c|c|c|}
\hline \multirow{2}{*}{$\begin{array}{l}\text { Nutrient } \\
(\mathrm{g} / \mathrm{kg} \text { of } \mathrm{DM})\end{array}$} & \multicolumn{2}{|c|}{ Concentrate } & \multicolumn{2}{|c|}{ Roughage } \\
\hline & Prepartum $^{1}$ & Postpartum $^{2}$ & Corn & Grass \\
\hline Crude ash & 42 & 47 & 36 & 94 \\
\hline $\mathrm{CP}$ & 230 & 228 & 120 & 136 \\
\hline Ether extract & 39 & 39 & 29 & 32 \\
\hline $\mathrm{ADF}$ & 45 & 44 & 222 & 310 \\
\hline NDF & 163 & 152 & 461 & 506 \\
\hline
\end{tabular}


10 min at $4^{\circ} \mathrm{C}$, supernatants were stored at $-20^{\circ} \mathrm{C}$ until analysis. Ten micrograms of protein were separated by SDS-PAGE and transferred to nitrocellulose membranes. After blocking, the membranes were incubated with a goat anti-HM74A (HCAR2) antibody (Santa Cruz Biotechnology Inc., Santa Cruz, CA) overnight at $4^{\circ} \mathrm{C}$ and subsequently with an anti-goat HRP secondary antibody (Sigma Aldrich) for $1 \mathrm{~h}$ at room temperature. Immunodetection was performed by incubating the membranes with SuperSignal West Dura substrate (Thermo Scientific, Rockford, IL) and chemiluminescence was detected by a ChemiDoc XRS+ system (BioRad Laboratories GmbH, Munich, Germany). After immunodetection, India ink staining was included as a loading control (an exemplary membrane showing the India ink staining was included as Supplementary Figure S1; http://dx.doi.org/10.3168/jds.2015-10131). Bands were quantified by densitometry using Image Lab 4.0 software (Bio-Rad Laboratories $\mathrm{GmbH}$ ).

\section{RNA Extraction, Purification, and Quality Control}

The SCAT and RPAT biopsy samples (200 mg each) were homogenized in QIAzol (Qiagen, Hilden, Germany) using the Precellys 24 system (Peqlab Biotechnologie GmbH, Erlangen, Germany). Total RNA was extracted with Qiazol (Qiagen) and purification was done using spin columns, including a selective DNA removal during the lysis step (InviTrap Spin Universal RNA Mini Kit, Stratec Molecular GmbH, Berlin, Germany). The concentration and the purity of the RNA obtained were assessed with the Nanodrop 1000 (Peqlab Biotechnologie $\mathrm{GmbH}$ ) by absorbance reading at 260 and $280 \mathrm{~nm}$. The RNA integrity was controlled by microcapillary electrophoresis using the Bioanalyzer 2100 (Agilent, Waldbronn, Germany) and the RNA 6000 Nano Kit (Agilent) to determine RNA integrity number, which was $6.4 \pm 0.08$.

\section{cDNA Synthesis}

Complementary DNA synthesis was performed with $500 \mathrm{ng}$ of total RNA per $40-\mu \mathrm{L}$ reaction volume with Random Hexamer primers (250 pmol, Sigma Aldrich) and RevertAid Reverse Transcriptase (Thermo Fisher Scientific, Waltham, MA) using $2 \mu \mathrm{L}$ of dNTP Mix (10 $\mathrm{m} M$ of each dNTP, Thermo Fisher Scientific) on the Thermocycler Alpha-SC (Analytik Jena, Jena, Germany). Each run included a negative template control and a no reverse transcriptase control. To alleviate the variation in cDNA synthesis, reverse transcription was performed in duplicates per tissue. Subsequently, duplicates were pooled, diluted $1: 4$, and stored at $-20^{\circ} \mathrm{C}$ until analysis.

\section{Relative Quantification of mRNA}

Relative quantification of the target genes was performed with standard curves based on purified amplicons, except in the case of $H C A R 1$, where serial dilutions of cDNA were used. As controls, the no template control and no reverse transcriptase control of the cDNA synthesis were carried along, together with a no template control for each PCR run, containing 2 $\mu \mathrm{L}$ of water instead of diluted template. The reactions were performed in Mx3000P qPCR systems (Stratagene, Amsterdam, the Netherlands, and Agilent, Santa Clara, CA) with a total volume of $10 \mu \mathrm{L}$, including 2 $\mu \mathrm{L}$ of cDNA (diluted 1:4), $1 \mu \mathrm{L}$ of primer mix, $2 \mu \mathrm{L}$ of water, and $5 \mu \mathrm{L}$ of SYBR Green JumpStart Taq Readymix (Sigma-Aldrich, Nümbrecht, Germany). The sequences of the primers used and their respective conditions for quantitative PCR are provided in Table 2. Specificity of the PCR products was confirmed for each primer by sequencing.

\section{Reference Gene Stability}

Reference genes were selected according to Saremi et al. (2012) and evaluated using qBase ${ }^{\text {PLUS }} 2.0$ (Biogazelle, Ghent, Belgium). All subsequent calculations and data quality controls were done based on this software (Hellemans et al., 2007). As final reference genes, lipoprotein receptor-related protein-10 and emerin were used for SCAT. For RPAT, lipoprotein receptor-related protein-10, emerin, RNA polymerase II, marvel domain containing 1 , and eukaryotic translation initiation factor 3 , subunit $\mathrm{K}$ appeared to be the most stable reference genes. For comparing both tissues, samples of SCAT and RPAT were normalized together using the reference genes of RPAT and, additionally, hippocalcin-like 1. Efficiency-corrected data are presented as ratios of the target genes mRNA abundance and the geometric mean of the respective reference genes.

\section{Statistical Analyses}

Statistical analyses were performed using SPSS (version 22.0, SPSS, IBM Corp., Armonk, NY) logtransformed mRNA data. No treatment effects were observed and, therefore, data from the different feeding groups were merged for further analysis. The repeated comparison for the serum as well as the mRNA data between each time point was done using the mixed model procedure. The examined factors were considered as dependent variables; the level of concentrate and the niacin supplementation were incorporated as fixed effects, sampling day as repeated effect, and the respective interactions were included into the model. A 


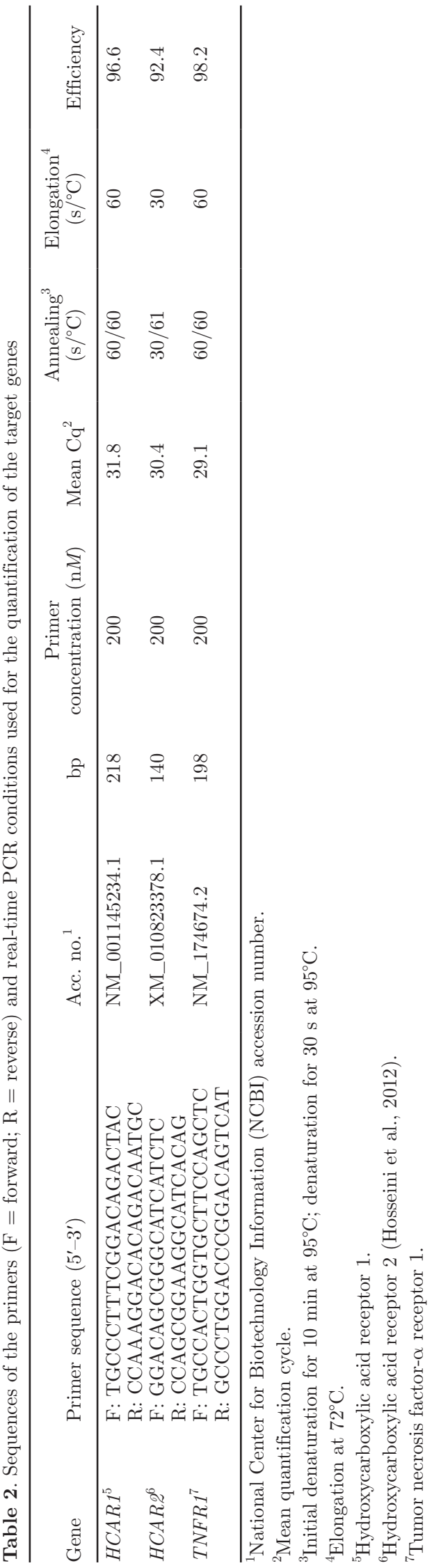

covariance structure autoregressive (first-order autoregressive structure with homogenous variances) followed by Bonferroni correction was used. For apelin, d -42 values were considered as covariates. The Student's $t$-test was applied for assessing differences between SCAT and RPAT at each individual time point. Pearson correlation coefficient was calculated for assessing correlations. Data are expressed as means \pm SEM. Statistical significance was set at $P<0.05$ and trends were defined as $0.05<P<0.1$.

\section{RESULTS}

\section{Energy Balance and Mobilization of Body Fat}

The strategy of feeding different portions of concentrate, supplemented with niacin, did not affect lipomobilization postpartum, as indicated by the BCS as well as BHB and fatty acid concentrations (Tienken et al., 2015). Also, the energy balance was not affected by the feeding scheme postpartum (Tienken et al., 2015). Further, performance data and results of blood metabolite analysis during the dry period and during lactation are provided as Supplementary Tables S1 and S2 (http:// dx.doi.org/10.3168/jds.2015-10131).

\section{Apelin}

For apelin, no treatment effects were observed and the serum concentrations remained unchanged from late pregnancy to lactation, on average $1.21 \pm 0.08 \mathrm{ng} /$ $\mathrm{mL}$ (Figure 1A).

\section{Resistin}

The serum resistin concentrations were not influenced by treatment, but changes related to time were observed. Serum resistin concentrations increased from d 42 a.p. until d 3 p.p. $(P<0.05)$ and decreased again to prepartum values until d 21 p.p. $(P<0.01)$. From d 21 to 100 , resistin remained at a constant level (Figure 1B). Significant correlations with other variables assessed are presented in Table 3.

\section{Lactate}

The serum concentrations of lactate were not affected by treatment but showed a gradual decrease during the observed period $(P<0.001)$, as shown in Figure 2 .

\section{HCAR1, HCAR2, and TNFR1 mRNA}

No differences were observed between the treatment groups, and thus merged data were analyzed for time- 

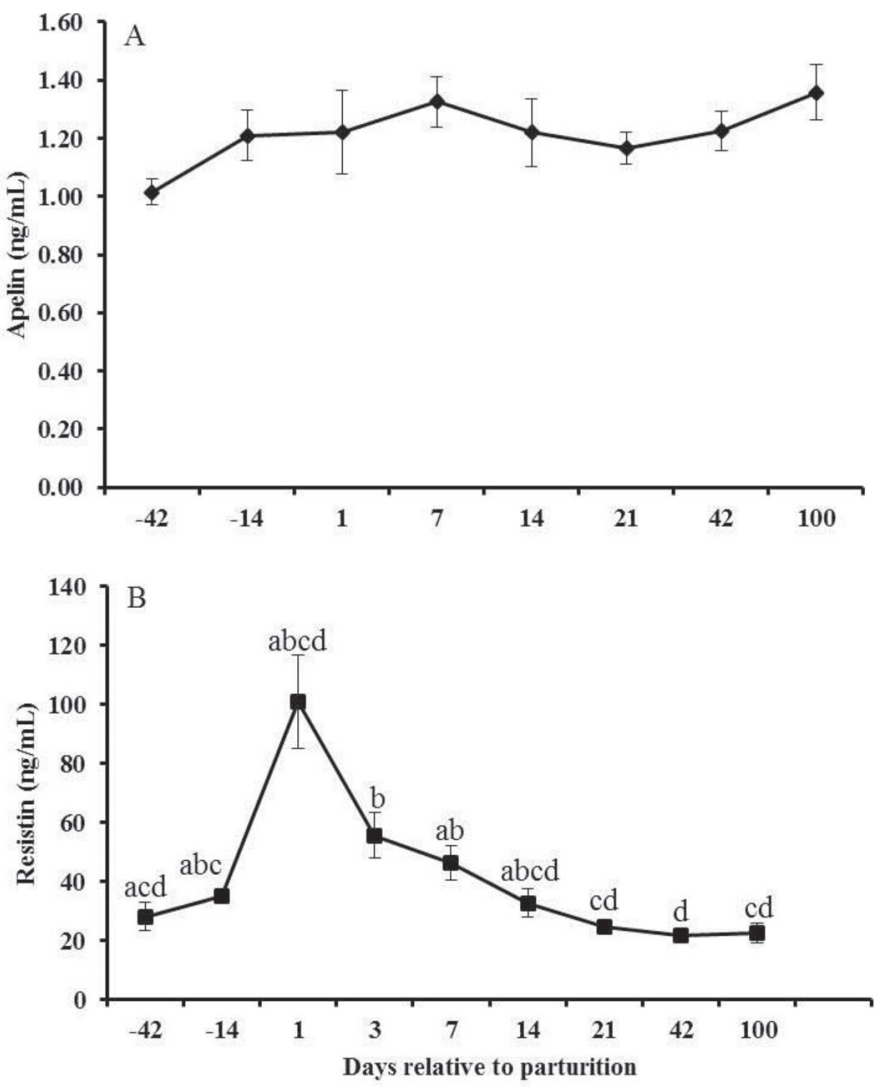

Figure 1. Time course of serum apelin (A) and resistin (B) concentrations from late pregnancy to early lactation of pluriparous dairy cows (means \pm SEM). Different letters (a-d) indicate significant differences between the individual sampling dates $(P<0.05)$.

dependent effects. The expression profiles for all 3 genes differed between SCAT and RPAT, as demonstrated in Figure 3. Comparing SCAT and RPAT, the HCAR1 mRNA abundance was greater in RPAT than in SCAT on $\mathrm{d} 42$ a.p. and 21 p.p. $(P<0.001)$. The HCAR2

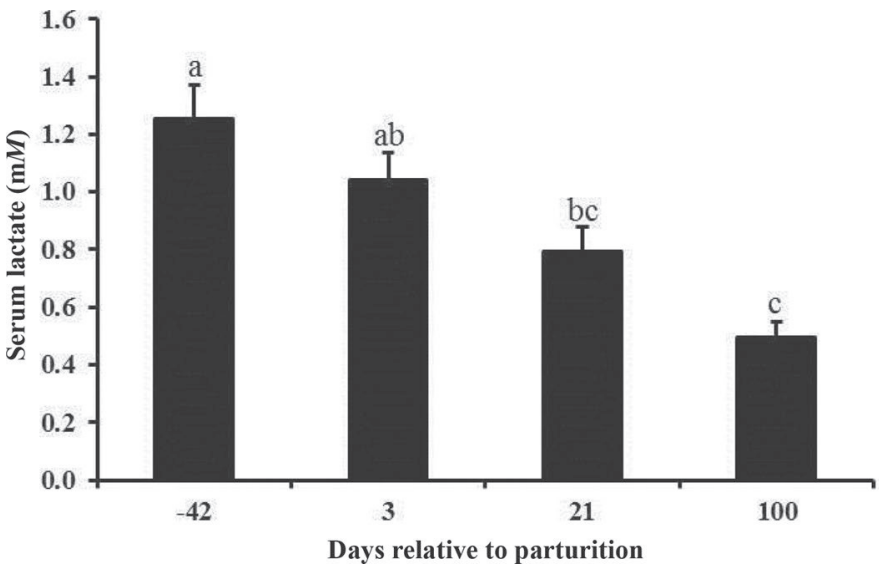

Figure 2. Serum L-lactate concentrations on d $-42,3,21$, and 100 relative to parturition in pluriparous dairy cows (means \pm SEM). Different letters $(\mathrm{a}-\mathrm{c})$ indicate significant differences between the individual sampling dates $(P<0.05)$. SCAT $=$ subcutaneous adipose tissue; $\mathrm{RPAT}=$ retroperitoneal adipose tissue.

mRNA abundance was significantly greater $(P<0.05)$ in RPAT than in SCAT at all sampling days (Figure 3 ). When comparing both AT depots, the TNFR1 mRNA abundance in RPAT was greater than in SCAT on $d$ 42 a.p. $(P<0.05)$ and d 21 p.p. $(P<0.01$; Figure $3)$. The results are presented in detail in Figure 3 and correlations with other variables tested are reported in Table 3.

\section{HCAR2 Protein Expression}

For HCAR2 protein expression, time-dependent effects were observed but treatment-dependent effects were not. In SCAT, the HCAR2 protein was increased from d 42 a.p. to d 100 p.p. $(P<0.001)$, whereas in RPAT no time-related changes were observed. Further details are presented in Figure 4.

Table 3. Coefficients of correlation (Pearson) for assessing relationships between the mRNA abundances of HCAR1, HCAR2, and TNFR1 as well as the serum concentrations of apelin, resistin, glucose, fatty acids, BHB, and lactate in subcutaneous (SCAT) and retroperitoneal adipose tissue (RPAT) of pluriparous dairy cows $(P<0.05)$

\begin{tabular}{|c|c|c|c|c|c|c|c|c|}
\hline Item & Apelin & Resistin & \multicolumn{3}{|c|}{ SCAT } & \multicolumn{3}{|c|}{ RPAT } \\
\hline $\begin{array}{l}\text { HCAR1 } \\
\text { HCAR2 } \\
\text { TNFR1 }\end{array}$ & & & & 0.507 & $\begin{array}{l}0.666 \\
0.549\end{array}$ & & 0.603 & $\begin{array}{l}0.467 \\
0.587\end{array}$ \\
\hline $\begin{array}{l}\text { Apelin } \\
\text { Resistin }\end{array}$ & & NS & $\begin{array}{l}0.372 \\
0.261\end{array}$ & NS & 0.315 & $\begin{array}{l}\text { NS } \\
\text { NS }\end{array}$ & NS & NS \\
\hline
\end{tabular}




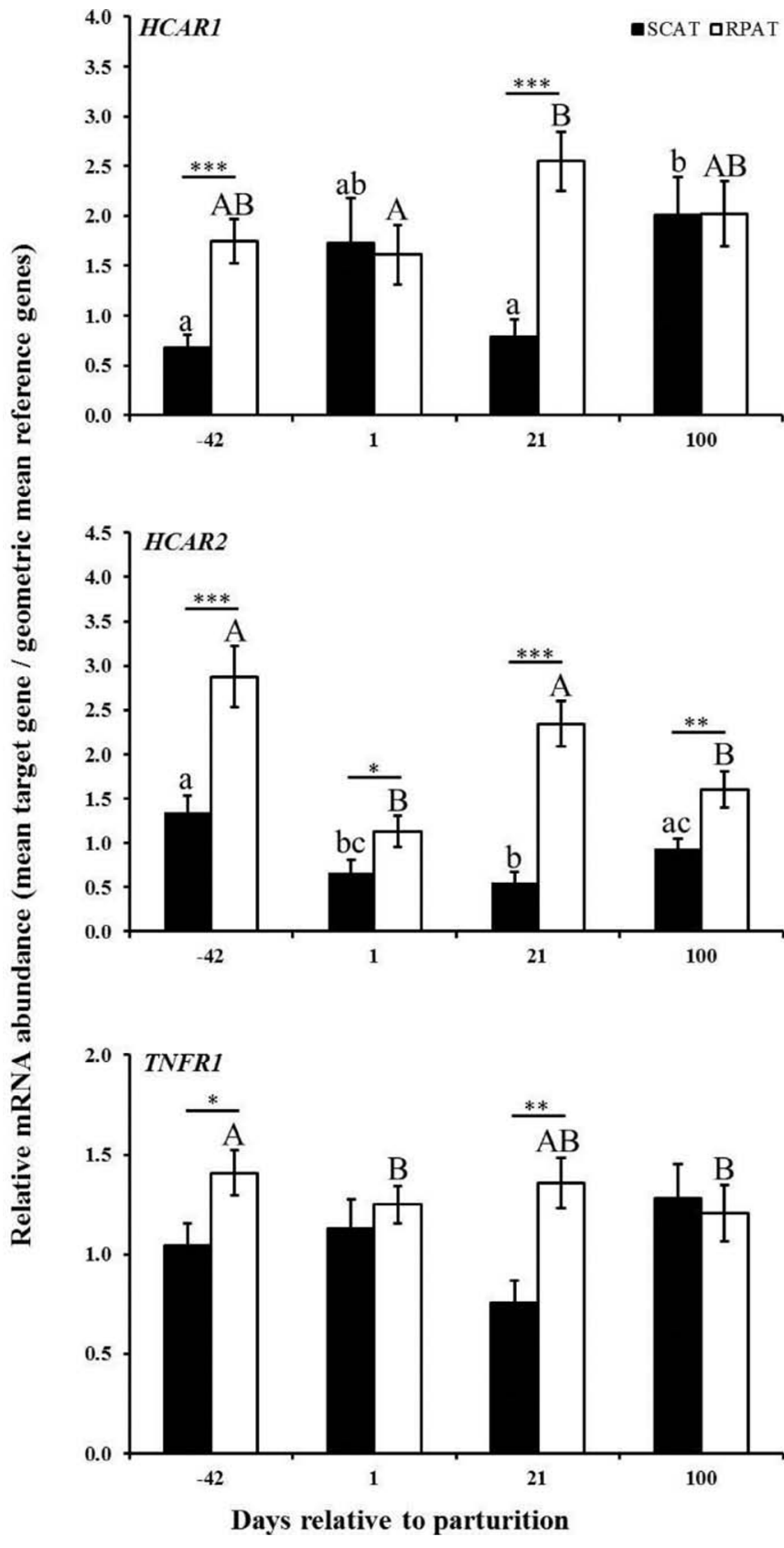

Figure 3. Messenger RNA expression of hydroxycarboxylic acid receptor 1 (HCAR1), hydroxycarboxylic acid receptor 2 (HCAR2), and tumor necrosis factor- $\alpha$ receptor 1 (TNFR1) on d $-42,1,21$, and 100 relative to parturition in subcutaneous (SCAT) and retroperitoneal adipose tissue (RPAT) of pluriparous dairy cows (means \pm SEM). Different lowercase letters $(\mathrm{a}-\mathrm{c})$ indicate significant differences between the individual sampling dates in SCAT $(P<0.05)$, whereas different uppercase letters $(\mathrm{A}, \mathrm{B})$ designate differences between the sampling dates in RPAT $(P<0.05)$. Asterisks mark a different mRNA abundance between SCAT and RPAT at the respective time points $\left({ }^{*} P<0.05,{ }^{* *} P<0.01,{ }^{* * *} P<0.001\right)$. For normalization lipoprotein receptor-related protein-10 ( $L R P 10)$ and emerin $(E M D)$ in SCAT, and LRP10, EMD, RNA polymerase II (POLR2A), marvel domain containing 1 (MARVELD1), and eukaryotic translation initiation factor 3, subunit $\mathrm{K}(E I F 3 K)$ in RPAT were used as reference genes. For comparing SCAT and RPAT, LRP10, EMD, POLR2A, MARVELD, EIF3K, and hippocalcin-like 1 (HPCAL) were used as reference genes.

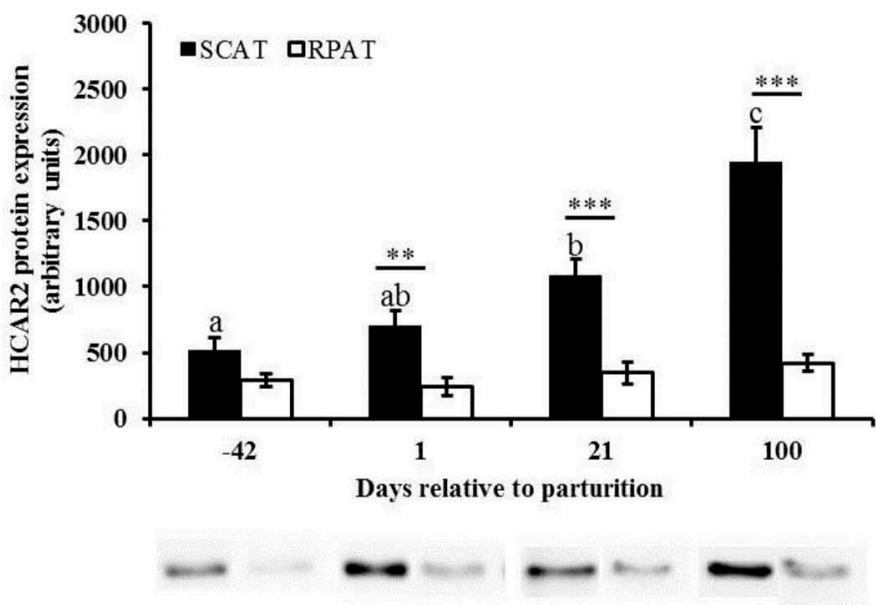

Figure 4. Protein expression of hydroxycarboxylic acid receptor (HCAR2) in subcutaneous (SCAT) and retroperitoneal adipose tissue (RPAT) on d $-42,1,21$, and 100 relative to parturition in pluriparous dairy cows (means \pm SEM). Different letters $(a-c)$ indicate significant differences between the individual sampling dates in SCAT $(P$ $<0.05)$. Asterisks mark a different protein expression between SCAT and RPAT at the respective time points $\left({ }^{*} P<0.05,{ }^{*} P<0.01\right.$, ${ }^{*} * * P$ $<0.001)$. India ink staining was included as a loading and transfer control. Representative immunoblots are shown below the respective bars.

\section{DISCUSSION}

In our study, the examined variables were mostly changing over time and showed AT depot-specific mRNA expression patterns. The prepartal feeding of different diets with regard to structure and energy content did not result in postpartum differences of energy balance, BCS, and lipolysis, as indicated by fatty acids and BHB concentrations in blood (Tienken et al., 2015). For the considered factors, no treatment effects were observed.

\section{Apelin}

Apelin improves muscular glucose uptake in mice (Dray et al., 2008) and has been regarded as a biomarker that improves the prediction of type 2 diabetes in men (Ma et al., 2014). The apelin concentrations in serum from late pregnancy until d 100 of lactation in dairy cows remained at a fairly constant level. As a consequence, apelin seems unsuitable to assess the metabolic status of dairy cows during the time interval investigated herein, which is associated with decreasing insulin sensitivity during early lactation (Bell, 1995). The constant serum concentrations we observed in cows are in accordance with results obtained in rodents in which the apelin concentrations in plasma were not related to pregnancy and lactation (Kawamata et al., 2001). Apelin peptides are derived from a 55-AA pro- 
apelin, containing $23 \mathrm{AA}$ in its C-terminal part, which are fully conserved between human and bovine (Lee et al., 2000). This proapelin is cleaved into different bioactive peptides with 13 (apelin-13) to 36 (apelin-36) AA in the C-terminal part (Tatemoto et al., 1998). These peptides show distinct affinities for the apelin receptor APJ (i.e., apelin-13 binds more effective than apelin-36; Hosoya et al., 2000). With the ELISA used herein, the total serum apelin concentrations were measured. It might be possible that the proportion of the different apelin peptides changed during the observed time without affecting the overall apelin concentration in serum. As a preferential cleavage of proapelin to apelin-13 without production of longer isoforms was shown (Shin et al., 2013), we cannot exclude that the effects are mediated via the binding affinity of apelin to APJ rather than by changes in serum concentration. Comparing apelin blood and tissue concentrations, the apelin concentration observed in blood was markedly lower than those in different tissues (e.g., lung, testis, and mammary gland, as observed in rats; Kawamata et al., 2001). Due to this observation, we speculated that apelin functions in a paracrine rather than endocrine manner, which might be of importance in dairy cows.

\section{Resistin}

The serum resistin concentrations measured in pluriparous cows confirmed recently published results in primiparous cows, showing higher concentrations after parturition and a return to precalving levels within 6 wk after calving (Reverchon et al., 2014). Likewise, those authors detected a correlation of resistin and fatty acids as well as the stimulation of lipolysis by resistin in vitro. The high correlation between fatty acids and resistin observed in our study thus supports the data of Reverchon et al. (2014) that resistin is likely involved in the lipolytic regulation during the periparturient period.

\section{HCAR1 and Lactate}

It was not possible to confirm recently published results, where HCAR1 mRNA expression in visceral and SCAT of dairy cows was shown to depend on dietary energy supply (Ji et al., 2014). However, considering the serum lactate concentrations measured herein, which are in the physiologically normal range, it is arguable to which amount the receptor can be activated. The half-maximal effective concentration $\left(\mathrm{EC}_{50}\right)$ value for L-lactate on HCAR1 has been reported to be $4.95 \pm$ $0.42 \mathrm{mM}$ in dairy cows (Liu et al., 2009). The lactate concentrations assessed in our study were 4 to 10 fold lower and, thus, may not or may only marginally acti- vate the receptor. The increased HCAR1 mRNA abundance in SCAT at d 100 after parturition compared with d 42 a.p. points to a regulatory role in times of established lactation. The increasing HCAR1 mRNA expression from d 1 to 21 p.p. in RPAT, combined with the different abundance in SCAT and RPAT, further support the idea of a tissue-specific lipolytic regulation as well as a higher relevance for HCAR1 in RPAT in the periparturient period.

\section{HCAR2}

The observed decline of HCAR2 mRNA abundance in SCAT from d 42 a.p. until d 21 p.p. is in accordance with previously published results, where a trend toward a decreasing mRNA abundance during the transition period was identified (Lemor et al., 2009). The HCAR2 mRNA and HCAR2 protein both showed an increase from d 21 to 100 p.p. in SCAT. To evaluate the influence on lipolysis by HCAR2, the serum BHB concentrations have to be taken into account. The medium BHB concentrations of $0.75 \mathrm{mM}$ herein are below the threshold of $1.2 \mathrm{~m} M$ defined for ketonemic conditions (Enjalbert et al., 2001). In a recently published in vitro study, BHB could induce an antilipolytic effect only at concentrations of $5 \mathrm{~m} M$ (Kenéz et al., 2014). The receptor HCAR2 is part of a feedback mechanism downregulating lipolysis (Gille et al., 2008). The timedependent changes of the HCAR2 mRNA, as well as the HCAR2 protein abundance in SCAT, may indicate lipolytic regulation at the level of the receptor quantity rather than on the concentration of its endogenous ligand BHB during times when the respective BHB concentrations are low. The HCAR2 protein expression was higher in SCAT than in RPAT on d 1, 21, and 100 after parturition. This points to a different relevance of the receptors in SCAT and RPAT and supports the notion of a different lipolytic capacity of SCAT and RPAT during the observed time.

\section{TNFR1}

The receptor TNFR1 has been shown to be necessary for TNF- $\alpha$-stimulated lipolysis and the inhibition of insulin-stimulated glucose uptake in adipocytes (Sethi et al., 2000). The constant TNFR1 mRNA abundance in SCAT and the time-dependent changes in RPAT further point to a tissue-specific lipolytic regulation, as already discussed. The receptor TNFR1, a strong activator of nuclear factor- $\kappa \mathrm{B}$ mediates the proinflammatory activities of TNF- $\alpha$ (Puimège et al., 2014). In view of inflammatory pathways being involved in the homeorhetic adaptations to lactation (Farney et al., 2013), our results indicate that TNFR1 might play a 
role during this time in RPAT in which more TNFR1 mRNA was detected. The constant TNFR1 mRNA abundance in SCAT is in line with recently published data on $T N F-\alpha$ mRNA abundance, where no changes related to parturition and lactation were noted but AT depot-dependent differences were found (Friedrichs et al., 2014). Based on the results of Friedrichs et al. (2014) on TNF- $\alpha$ data and our data on TNFR1, local regulation of insulin sensitivity may take place.

\section{Relationship Between the Considered Factors}

The correlation studies showed no significant relation between serum apelin and glucose concentrations. However, a positive correlation was found for apelin and TNFR1 in SCAT but not in RPAT. This might indicate a tissue-specific effect of apelin on insulin sensitivity and supports the notion of a tissue-specific regulation of insulin sensitivity (Saremi et al., 2014). A positive correlation between HCAR1 and HCAR2 was detected in both AT depots. This finding might indicate a coregulation in the context of controlling lipolysis. The receptor TNFR1 was positively correlated with $H C A R 1$ and HCAR2 in both examined AT depots. Together with a higher TNFR1 mRNA abundance at d 42 a.p. and d 21 p.p. in RPAT, this also supports the hypothesis of a differential lipolytic regulation in SCAT and RPAT. No correlation was found between serum lactate concentrations and HCAR1 mRNA abundance. Thus, the ligand most likely does not regulate the receptor mRNA expression. Ahmed et al. (2010) postulated that lactate released from adipocytes acts in an auto- and paracrine manner to induce antilipolytic effects when plasma glucose levels are increased. This might explain the lacking correlation between HCAR1 and serum lactate concentrations herein and indicates that the local lactate concentrations might be more relevant than the systemic ones. In our study, HCAR2 mRNA in both SCAT and RPAT was positively correlated with serum glucose. This suggests a functional link between HCAR2 and serum glucose concentrations to save energy in the form of triglycerides in dairy cows when glucose concentrations are elevated, a link that is also supported by in vivo glucose infusions resulting in increased lipogenesis (Al-Trad et al., 2009, Carra et al., 2013). The negative correlation with serum BHB concentrations might indicate a negative feedback loop that downregulates HCAR2 when BHB concentrations are high to ensure lipolysis in dairy cows.

\section{CONCLUSIONS}

Our results indicate a relationship between HCAR1, HCAR2, and TNFR1 on the level of transcription and point to a regulatory role in lipolysis during the transition period and in early lactation. Furthermore, we provide the first insight into the longitudinal regulation of HCAR1 mRNA. A serum apelin profile for the corresponding period was recorded. Further studies are required to elucidate the functional roles of apelin and its receptor in glucose metabolism.

\section{ACKNOWLEDGMENTS}

The authors thank the German Research Foundation (Bonn) for financial support (SA 432/11-1, DA 558/61, HU 838/12-1, RE 819/7-1). The authors thank all the co-workers of the Institute of Animal Nutrition in Braunschweig and the University of Veterinary Medicine in Hannover who supported this work and assisted in animal care, sample collection, and data collection. Special gratitude is dedicated to Birgit Mielenz (formerly Institute of Animal Science, Physiology and Hygiene Unit, University of Bonn, Germany; currently Institute of Nutrition Physiology "Oskar Kellner," Leibniz Institute for Farm Animal Biology, Germany), Isabella Israel, and Inga Hofs (both of Institute of Animal Science, Physiology and Hygiene Unit, University of Bonn, Germany) for their excellent technical assistance, to Laura Webb (Institute of Animal Science, Physiology \& Hygiene Unit, University of Bonn) for her help during the sampling of the cows, as well as to Julius Küsters (Department of Physiology, University of Veterinary Medicine Hannover, Germany) for performing the lactate analyses. We thank Taylor \& Francis Ltd. (www.tandfonline.com) for the opportunity to use data for the Supplemental Tables S1 and S2.

\section{REFERENCES}

Ahmed, K., S. Tunaru, C. Tang, M. Muller, A. Gille, A. Sassmann, J. Hanson, and S. Offermanns. 2010. An autocrine lactate loop mediates insulin-dependent inhibition of lipolysis through GPR81. Cell Metab. 11:311-319.

Al-Trad, B., K. Reisberg, T. Wittek, G. B. Penner, A. Alkaassem, G. Gabel, M. Furll, and J. R. Aschenbach. 2009. Increasing intravenous infusions of glucose improve body condition but not lactation performance in midlactation dairy cows. J. Dairy Sci. 92:5645-5658.

Aschenbach, J. R., N. B. Kristensen, S. S. Donkin, H. M. Hammon, and G. B. Penner. 2010. Gluconeogenesis in dairy cows: The secret of making sweet milk from sour dough. IUBMB Life 62:869-877.

Aydin, S. 2013. Presence of adropin, nesfatin-1, apelin-12, ghrelins and salusins peptides in the milk, cheese whey and plasma of dairy cows. Peptides 43:83-87.

Bauman, D. E., and W. B. Currie. 1980. Partitioning of nutrients during pregnancy and lactation: A review of mechanisms involving homeostasis and homeorhesis. J. Dairy Sci. 63:1514-1529.

Bell, A. W. 1995. Regulation of organic nutrient metabolism during transition from late pregnancy to early lactation. J. Anim. Sci. $73: 2804-2819$

Bell, A. W., and D. E. Bauman. 1997. Adaptations of glucose metabolism during pregnancy and lactation. J. Mammary Gland Biol. Neoplasia 2:265-278. 
Björntorp, P. 1990. "Portal" adipose tissue as a generator of risk factors for cardiovascular disease and diabetes. Arteriosclerosis 10:493-496.

Boucher, J., B. Masri, D. Daviaud, S. Gesta, C. Guigne, A. Mazzucotelli, I. Castan-Laurell, I. Tack, B. Knibiehler, C. Carpene, Y. Audigier, J. S. Saulnier-Blache, and P. Valet. 2005. Apelin, a newly identified adipokine up-regulated by insulin and obesity. Endocrinology 146:1764-1771.

Cai, T. Q., N. Ren, L. Jin, K. Cheng, S. Kash, R. Chen, S. D. Wright, A. K. Taggart, and M. G. Waters. 2008. Role of GPR81 in lactatemediated reduction of adipose lipolysis. Biochem. Biophys. Res. Commun. 377:987-991.

Carra, M., B. Al-Trad, G. B. Penner, T. Wittek, G. Gabel, M. Fur, and J. R. Aschenbach. 2013. Intravenous infusions of glucose stimulate key lipogenic enzymes in adipose tissue of dairy cows in a dose-dependent manner. J. Dairy Sci. 96:4299-4309.

Daviaud, D., J. Boucher, S. Gesta, C. Dray, C. Guigne, D. Quilliot, A. Ayav, O. Ziegler, C. Carpene, J. S. Saulnier-Blache, P. Valet, and I. Castan-Laurell. 2006. TNFalpha up-regulates apelin expression in human and mouse adipose tissue. FASEB J. 20:1528-1530.

Drackley, J. K. 1999. ADSA Foundation Scholar Award. Biology of dairy cows during the transition period: The final frontier? J. Dairy Sci. 82:2259-2273.

Dray, C., C. Knauf, D. Daviaud, A. Waget, J. Boucher, M. Buleon, P. D. Cani, C. Attane, C. Guigne, C. Carpene, R. Burcelin, I. Castan-Laurell, and P. Valet. 2008. Apelin stimulates glucose utilization in normal and obese insulin-resistant mice. Cell Metab. 8:437-445

Duncan, R. E., M. Ahmadian, K. Jaworski, E. Sarkadi-Nagy, and H. S. Sul. 2007. Regulation of lipolysis in adipocytes. Annu. Rev. Nutr. 27:79-101.

Enjalbert, F., M. C. Nicot, C. Bayourthe, and R. Moncoulon. 2001. Ketone bodies in milk and blood of dairy cows: Relationship between concentrations and utilization for detection of subclinical ketosis. J. Dairy Sci. 84:583-589.

Farney, J. K., L. K. Mamedova, J. F. Coetzee, B. KuKanich, L. M. Sordillo, S. K. Stoakes, J. E. Minton, L. C. Hollis, and B. J. Bradford. 2013. Anti-inflammatory salicylate treatment alters the metabolic adaptations to lactation in dairy cattle. Am. J. Physiol. Regul. Integr. Comp. Physiol. 305:R110-R117.

Friedrichs, P., B. Saremi, S. Winand, J. Rehage, S. Danicke, H. Sauerwein, and M. Mielenz. 2014. Energy and metabolic sensing G protein-coupled receptors during lactation-induced changes in energy balance. Domest. Anim. Endocrinol. 48:33-41.

Gille, A., E. T. Bodor, K. Ahmed, and S. Offermanns. 2008. Nicotinic acid: Pharmacological effects and mechanisms of action. Annu. Rev. Pharmacol. Toxicol. 48:79-106.

Grummer, R. R. 1995. Impact of changes in organic nutrient metabolism on feeding the transition dairy cow. J. Anim. Sci. 73:28202833.

Hellemans, J., G. Mortier, A. De Paepe, F. Speleman, and J. Vandesompele. 2007. qBase relative quantification framework and software for management and automated analysis of real-time quantitative PCR data. Genome Biol. 8:R19.

Hosoya, M., Y. Kawamata, S. Fukusumi, R. Fujii, Y. Habata, S. Hinuma, C. Kitada, S. Honda, T. Kurokawa, H. Onda, O. Nishimura, and M. Fujino. 2000. Molecular and functional characteristics of APJ. Tissue distribution of mRNA and interaction with the endogenous ligand apelin. J. Biol. Chem. 275:21061-21067.

Hosseini, A., C. Behrendt, P. Regenhard, H. Sauerwein, and M. Mielenz. 2012. Differential effects of propionate or beta-hydroxybutyrate on genes related to energy balance and insulin sensitivity in bovine white adipose tissue explants from a subcutaneous and a visceral depot. J. Anim. Physiol. Anim. Nutr. (Berl.) 96:570-580.

Jeninga, E. H., A. Bugge, R. Nielsen, S. Kersten, N. Hamers, C. Dani, M. Wabitsch, R. Berger, H. G. Stunnenberg, S. Mandrup, and E. Kalkhoven. 2009. Peroxisome proliferator-activated receptor gamma regulates expression of the anti-lipolytic G-protein-coupled receptor 81 (GPR81/Gpr81). J. Biol. Chem. 284:26385-26393.

Ji, P., J. K. Drackley, M. J. Khan, and J. J. Loor. 2014. Overfeeding energy upregulates peroxisome proliferator-activated receptor
(PPAR)gamma-controlled adipogenic and lipolytic gene networks but does not affect proinflammatory markers in visceral and subcutaneous adipose depots of Holstein cows. J. Dairy Sci. 97:34313440 .

Kawamata, Y., Y. Habata, S. Fukusumi, M. Hosoya, R. Fujii, S. Hinuma, N. Nishizawa, C. Kitada, H. Onda, O. Nishimura, and M. Fujino. 2001. Molecular properties of apelin: Tissue distribution and receptor binding. Biochim. Biophys. Acta 1538:162-171.

Kenéz, A., L. Locher, J. Rehage, S. Danicke, and K. Huber. 2014. Agonists of the G protein-coupled receptor 109A-mediated pathway promote antilipolysis by reducing serine residue 563 phosphorylation of hormone-sensitive lipase in bovine adipose tissue explants. J. Dairy Sci. 97:3626-3634.

Larsen, M., and N. B. Kristensen. 2009. Effect of abomasal glucose infusion on splanchnic amino acid metabolism in periparturient dairy cows. J. Dairy Sci. 92:3306-3318.

Lee, D. K., R. Cheng, T. Nguyen, T. Fan, A. P. Kariyawasam, Y. Liu, D. H. Osmond, S. R. George, and B. F. O'Dowd. 2000. Characterization of apelin, the ligand for the APJ receptor. J. Neurochem. $74: 34-41$.

Lemor, A., A. Hosseini, H. Sauerwein, and M. Mielenz. 2009. Transition period-related changes in the abundance of the mRNAs of adiponectin and its receptors, of visfatin, and of fatty acid binding receptors in adipose tissue of high-yielding dairy cows. Domest. Anim. Endocrinol. 37:37-44.

Liu, C., J. Wu, J. Zhu, C. Kuei, J. Yu, J. Shelton, S. W. Sutton, X. Li, S. J. Yun, T. Mirzadegan, C. Mazur, F. Kamme, and T. W. Lovenberg. 2009. Lactate inhibits lipolysis in fat cells through activation of an orphan G-protein-coupled receptor, GPR81. J. Biol. Chem. 284:2811-2822.

Locher, L. F., N. Meyer, E. M. Weber, J. Rehage, U. Meyer, S Danicke, and K. Huber. 2011. Hormone-sensitive lipase protein expression and extent of phosphorylation in subcutaneous and retroperitoneal adipose tissues in the periparturient dairy cow. J. Dairy Sci. 94:4514-4523.

Ma, W. Y., T. Y. Yu, J. N. Wei, C. S. Hung, M. S. Lin, Y. J. Liao, D. Pei, C. C. Su, K. C. Lu, P. H. Liu, C. H. Lin, L. M. Chuang, H. L. Kao, J. W. Lin, Y. J. Chuang, and H. Y. Li. 2014. Plasma apelin: A novel biomarker for predicting diabetes. Clin. Chim. Acta 435:18-23.

McNamara, J. P., and J. K. Hillers. 1986. Adaptations in lipid metabolism of bovine adipose tissue in lactogenesis and lactation. J Lipid Res. 27:150-157.

Offermanns, S., S. L. Colletti, T. W. Lovenberg, G. Semple, A. Wise, and A. P. IJzerman. 2011. International union of basic and clinical pharmacology. LXXXII: Nomenclature and classification of hydroxy-carboxylic acid receptors (GPR81, GPR109A, and GPR109B). Pharmacol. Rev. 63:269-290.

Palou, M., T. Priego, J. Sanchez, A. M. Rodriguez, A. Palou, and C. Pico. 2009. Gene expression patterns in visceral and subcutaneous adipose depots in rats are linked to their morphologic features. Cell. Physiol. Biochem. 24:547-556.

Puimège, L., C. Libert, and F. Van Hauwermeiren. 2014. Regulation and dysregulation of tumor necrosis factor receptor-1. Cytokine Growth Factor Rev. 25:285-300.

Rebuffé-Scrive, M., B. Andersson, L. Olbe, and P. Bjorntorp. 1989. Metabolism of adipose tissue in intraabdominal depots of nonobese men and women. Metabolism 38:453-458.

Reverchon, M., C. Rame, J. Cognie, E. Briant, S. Elis, D. Guillaume, and J. Dupont. 2014. Resistin in dairy cows: Plasma concentrations during early lactation, expression and potential role in adipose tissue. PLoS ONE 9:e93198.

Sadri, H., R. M. Bruckmaier, H. R. Rahmani, G. R. Ghorbani, I Morel, and H. A. van Dorland. 2010. Gene expression of tumour necrosis factor and insulin signalling-related factors in subcutaneous adipose tissue during the dry period and in early lactation in dairy cows. J. Anim. Physiol. Anim. Nutr. (Berl.) 94:e194-e202.

Saremi, B., H. Sauerwein, S. Danicke, and M. Mielenz. 2012. Technical note: Identification of reference genes for gene expression studies in different bovine tissues focusing on different fat depots. J. Dairy Sci. 95:3131-3138. 
Saremi, B., S. Winand, P. Friedrichs, A. Kinoshita, J. Rehage, S. Danicke, S. Haussler, G. Breves, M. Mielenz, and H. Sauerwein. 2014. Longitudinal profiling of the tissue-specific expression of genes related with insulin sensitivity in dairy cows during lactation focusing on different fat depots. PLoS ONE 9:e86211.

Sethi, J. K., H. Xu, K. T. Uysal, S. M. Wiesbrock, L. Scheja, and G. S. Hotamisligil. 2000. Characterisation of receptor-specific TNFalpha functions in adipocyte cell lines lacking type 1 and 2 TNF receptors. FEBS Lett. 469:77-82.

Shin, K., A. Pandey, X. Q. Liu, Y. Anini, and J. K. Rainey. 2013. Preferential apelin-13 production by the proprotein convertase PCSK3 is implicated in obesity. FEBS Open Bio 3:328-333.

Smith, S. R., and J. J. Zachwieja. 1999. Visceral adipose tissue: A critical review of intervention strategies. Int. J. Obes. Relat. Metab. Disord. 23:329-335.

Steppan, C. M., S. T. Bailey, S. Bhat, E. J. Brown, R. R. Banerjee, C. M. Wright, H. R. Patel, R. S. Ahima, and M. A. Lazar. 2001. The hormone resistin links obesity to diabetes. Nature 409:307-312.

Sumner, J. M., and J. P. McNamara. 2007. Expression of lipolytic genes in the adipose tissue of pregnant and lactating Holstein dairy cattle. J. Dairy Sci. 90:5237-5246.

Sumner-Thomson, J. M., J. L. Vierck, and J. P. McNamara. 2011. Differential expression of genes in adipose tissue of first-lactation dairy cattle. J. Dairy Sci. 94:361-369.

Tatemoto, K., M. Hosoya, Y. Habata, R. Fujii, T. Kakegawa, M. X. Zou, Y. Kawamata, S. Fukusumi, S. Hinuma, C. Kitada, T. Kurokawa, H. Onda, and M. Fujino. 1998. Isolation and characterization of a novel endogenous peptide ligand for the human APJ receptor. Biochem. Biophys. Res. Commun. 251:471-476.
Tienken, R., S. Kersten, J. Frahm, U. Meyer, L. Locher, J. Rehage, K. Huber, A. Kenez, H. Sauerwein, M. Mielenz, and S. Danicke. 2015. Effects of an energy-dense diet and nicotinic acid supplementation on production and metabolic variables of primiparous or multiparous cows in periparturient period. Arch. Anim. Nutr. 69:319-339.

Titgemeyer, E. C., L. K. Mamedova, K. S. Spivey, J. K. Farney, and B. J. Bradford. 2011. An unusual distribution of the niacin receptor in cattle. J. Dairy Sci. 94:4962-4967.

Tunaru, S., J. Kero, A. Schaub, C. Wufka, A. Blaukat, K. Pfeffer, and S. Offermanns. 2003. PUMA-G and HM74 are receptors for nicotinic acid and mediate its anti-lipolytic effect. Nat. Med. 9:352-355.

von Soosten, D., U. Meyer, E. M. Weber, J. Rehage, G. Flachowsky, and S. Danicke. 2011. Effect of trans-10,cis-12 conjugated linoleic acid on performance, adipose depot weights, and liver weight in early-lactation dairy cows. J. Dairy Sci. 94:2859-2870.

Wise, A., S. M. Foord, N. J. Fraser, A. A. Barnes, N. Elshourbagy, M. Eilert, D. M. Ignar, P. R. Murdock, K. Steplewski, A. Green, A. J. Brown, S. J. Dowell, P. G. Szekeres, D. G. Hassall, F. H. Marshall, S. Wilson, and N. B. Pike. 2003. Molecular identification of high and low affinity receptors for nicotinic acid. J. Biol. Chem. 278:9869-9874.

Yue, P., H. Jin, S. Xu, M. Aillaud, A. C. Deng, J. Azuma, R. K. Kundu, G. M. Reaven, T. Quertermous, and P. S. Tsao. 2011. Apelin decreases lipolysis via G(q), G(i), and AMPK-dependent mechanisms. Endocrinology 152:59-68. 